DOI 10.22460/jpmi.v1i3.289-298

\title{
PERKEMBANGAN SISWA SMK KELAS X DALAM PEMBELAJARAN OPERASI BILANGAN
}

\author{
Padhila Angraini $^{1}$, Rully Charitas Indra Prahmana ${ }^{2}$, Ardhi Ardhian ${ }^{3}$ \\ ${ }^{1,2}$ Universitas Ahmad Dahlan, Jl. Prof. Dr. Soepomo, S.H., Janturan, Warungboto, Umbulharjo, \\ Yogyakarta, Indonesia \\ ${ }^{3}$ SMK Muhammadiyah 2 Bantul, Jl. Bajen, Kec. Bantul, Bantul, Yogyakarta, Indonesia \\ ${ }^{1}$ padhilaangraini.pa@gmail.com, ${ }^{2}$ rully.indra@mpmat.uad.ac.id, ${ }^{3}$ ardhiardhian@gmail.com
}

Diterima: 29 April 2018; Disetujui: 28 Mei 2018

\begin{abstract}
This study aims to determine about the development of students. This research method used is Single Subject Research (SSR) with basic design of A-B. The techniques of data collection used observation and interview to determine difficulties and the ability understanding mathematical students. The results of this study indicate that kontruktivisme approach can improve understanding mathematical students. It can be seen from the average score obtained by the student before the treatment given that is 11,75 and increased to 77,88 after treatment.
\end{abstract}

Keywords: Single Subject Research, Constructivism Approach, Understanding Mathematical, Operation of Number

\begin{abstract}
Abstrak
Tujuan penelitian adalah untuk mengetahui perkembangan siswa SMK. Penelitian ini menggunakan metode penelitian Single Subject Research (SSR) dengan desain dasar A-B. Subjek dalam penelitian ini yaitu siswa kelas X SMK Muhammadiyah 2 Bantul. Teknik pengumpulan data menggunakan metode observasi dan interview untuk mengetahui kesulitan dan kemampuan pemahaman matematis siswa. Hasil penelitian ini menunjukkan bahwa pendekatan kontruktivisme dapat meningkatkan pemahaman matematis siswa. Hal ini dapat dilihat dari skor rata-rata yang diperoleh siswa sebelum diberikan perlakuan yaitu 11,75 dan meningkat menjadi 77,88 setelah diberikan perlakuan.
\end{abstract}

Kata Kunci: Single Subject Research, Pendekatan Kontruktivisme, Pemahaman Matematis, Operasi Bilangan

How to cite: Anggraeni, P., Prahmana, R. C. I., \& Ardhian, A. (2018). Perkembangan Siswa SMK Kelas X dalam Pembelajaran Operasi Bilangan. JPMI - Jurnal Pembelajaran Matematika Inovatif, 1 (3), 289-298.

\section{PENDAHULUAN}

Matematika merupakan ilmu yang bersifat abstrak (Purnama \& Afriansyah, 2016; Niswarni, 2012; Prahmana, 2010). Hal ini diperkuat oleh Ningsih, Budiyono, \& Riyadi (2016); Ulfah \& Prahmana (2018); Isnaeni (2016); Fauziah, Parta, \& Rahardjo (2016) yang menyatakan bahwa matematika itu pelajaran yang sulit, banyak berisi rumus, dan menakutkan bagi siswa. Sejalan dengan itu, siswa mengalami kesulitan belajar dalam mempelajari materi matematika (Untari, 2013; Azis \& Sugiman, 2015; Kumalasari \& Sugiman, 2015); Prahmana (2010). Sehingga, kesulitan yang dialami siswa memungkinkan siswa melakukan kesalahan dalam menyelesaikan soal matematika (Untari, 2013; Putri, Kriswandani, \& Wahyudi, 2016). Sejalan dengan itu Azis \& Sugiman (2015) mengungkapkan bahwa kesalahan dapat 
ditunjukkan dengan menurunnya dan rendahnya prestasi belajar matematika siswa. Selanjutnya Nurlita (2015); Isnaeni (2016) menyatakan bahwa prestasi belajar matematika di indonesia masih tergolong rendah. Sehingga, matematika adalah ilmu yang bersifat abstrak dan sulit yang membuat siswa mengalami kesalahan dalam menyelesaikan soal matematika dan membuat prestasi belajar siswa menurun.

Belajar pada dasarnya harus menguasai 3 kemampuan yaitu membaca, menulis, dan berhitung (Sari, 2013). Untari (2013) menyatakan bahwa pembelajaran matematika tidak pernah terlepas dari operasi hitung baik operasi penjumlahan, pengurangan, perkalian maupun pembagian. Senada dengan itu Afriansyah \& Putri (2013) mengungkapkan bahwa siswa cenderung mengalami kesulitan dalam mengaplikasikan operasi bilangan desimal, seperti operasi penjumlahan desimal. Selain itu, siswa masih banyak mengalami kesulitan dalam operasi bilangan pecahan (Rahmawati, 2017). Oleh karena itu, pembelajaran matematika tidak akan lepas dari operasi hitung, seperti operasi hitung bilangan desimal dan bilangan pecahan.

Pembelajaran matematika seharusnya tidak hanya memberikan hafalan berupa metode prosedural dalam pemecahan masalah matematika, melainkan membangun pemahaman terhadap konsep matematika yang sedang dipelajari (Novindara, Sudaryati, \& Meiliasari, 2014). Selain itu, pemahaman matematis adalah pengetahuan siswa terhadap konsep, prinsip, prosedur, dan kemampuan siswa menggunakan strategi dalam menyelesaikan permasalahan matematika, ketika mereka membangun hubungan antara pengetahuan baru dengan pengetahuan sebelumnya (Alan \& Afriansyah, 2017; Kesumawati, 2014). Sehingga, dapat dikatakan bahwa pemahaman matematis adalah pemahaman terhadap konsep, prinsip, dan hubungan antara pengetahuan baru dengan pengetahuan sebelumnya.

Pendekatan konstruktivis dapat meningkatkan prestasi siswa (Riyanto, \& Siroj, 2011). Hal ini didukung oleh Ramellan, Musdi, \& Armiati (2012) mengemukakan bahwa pendekatan konstruktivis dapat membimbing siswa untuk mengkonstruksi pemahamannya terhadap materi yang diajarkan. Oleh karena itu, pendekatan kontruktivis dapat meningkatkan prestasi siswa dengan membimbing siswa untuk mengkonstruksi pemahaman matematisnya terhadap materi yang diajarkan.

Berdasarkan hasil observasi yang dilakukan peneliti pada tanggal 28 September 2017 di SMK Muhammadiyah 2 Bantul dengan guru matematika Ardhi Ardian,S.Si, dapat disimpulkan bahwa siswa yang menjadi subjek penelitian karena memiliki kekurangan dalam kemampuan operasi bilangan dan siswa tergolong memiliki kepribadian introvert yang ditunjukkan dengan sikap menyendiri, pendiam, dan berperilaku pasif. Sehingga, peneliti menggunakan Single Subject Research (SSR) sebagai jenis penelitian dengan tujuan untuk mengetahui kemampuan operasi bilangan pada siswa yang merupakan siswa SMK. Hal ini didukung oleh Ulfah \& Prahmana (2018) dengan hasil penelitian pembelajaran berbasis masalah mampu meningkatkan pemahaman matematis. Hal ini diperkuat dengan meningkatnya hasil kemampuan perkalian bilangan anak kesulitan belajar melalui media batang napier (Aristiani, 2013). Selanjutnya, kemampuan operasi perkalian yang hasil bilanganya dua angka untuk anak diskalkulia dapat ditingkatkan dengan metode garismatik (Arisandi, 2014).

\section{METODE}

Penelitian ini merupakan penelitian Single Subject Research (SSR) yang bertujuan untuk mengetahui perkembangan siswa SMK dalam operasi bilangan pengurangan, penjumlahan, perkalian dan pembagian pada siswa SMK Muhammadiyah 2 Bantul. 
Pada disain subjek tunggal pengukuran variabel terikat atau target behavior dilakukan berulang-ulang dengan periode waktu tertentu misalnya perminggu, perhari, atau perjam, perbandingan tidak dilakukan antar individu maupun kelompok tetapi dibandingkan pada siswa yang sama dalam kondisi yang berbeda (Sunanto, dkk., 2005). Oleh karena itu, dalam penelitian ini, peneliti melakukan pengukuran yang sama dan berulang-ulang untuk mempelajari berapa banyak perubahan yang terjadi pada variabel terikat (dependent) perhari.

Kondisi disini adalah kondisi baseline dan kondisi eksperimen (intervensi). Kondisi disini adalah kondisi baseline yang merupakan kondisi dimana pengukuran target behavior dilakukan pada keadaan natural sebelum diberikan intervensi apapun dan kondisi eksperimen adalah kondisi dimana suatu intervensi telah diberikan, sehingga target behavior diukur di bawah kondisi tersebut (sunanto, dkk. 2015).

Dalam penelitian ini peneliti menggunakan desain A-B. Desain A-B pada dasarnya tidak ada replikasi (pengulangan) pengukuran dimana fase baseline (A) dan intervensi (B) masingmasing dilakukan hanya sekali untuk siswa yang sama, oleh karena itu, dengan disain ini tidak dapat disimpulkan atau tidak ada jaminan bahwa perubahan pada target behavior disebabkan semata-mata oleh variabel bebas (intervensi) (sunanto, dkk. 2005). Adapun perilaku yang diukur dalam penelitian ini adalah pendekatan kontruktivisme terhadap tingkat pemahaman matematis siswa dalam operasi bilangan.

\section{HASIL DAN PEMBAHASAN}

\section{Hasil}

Penelitian ini dilaksanakan di SMK Muhammadiyah 2 Bantul. Hasil penelitiannya Single Subject Research (SSR) dengan menggunakan desain A (Baseline) dan B (Intervensi), kemudian data yang diperoleh dianalisis dengan menggunakan analisis visual data grafik (Visual Analisys Of Graphic Data). Adapun data yang diperoleh dari hasil pengamatan pada kondisi pada kondisi A (baseline sebelum diberikan intervensi). Kondisi B (intervensi setelah diberikan perlakuan). Hasil penelitian ini akan mengungkapkan meningkatnya kemampuan pemahaman matematis siswa pada pembelajaran matematika melalui pendekatan kontruktivis. Data ini dihasilkan dari hasil penelitian selama sembilan hari, dengan pembagian 4 hari (satu hari 1 sesi selama 45 menit ) yang kemudian disebut baseline, sedangkan intervensi dilakukan selama 7 hari (satu hari 1 sesi selama 90 menit). Adapun hasil evaluasi siswa penelitian terdapat pada Tabel 1.

Tabel 1. Skor Siswa

\begin{tabular}{lll}
\hline & Tanggal & SKOR \\
\hline & 28 Maret 2018 & 13 \\
29 Maret 2018 & 11 \\
BASELINE & 31 Maret 2018 & 10 \\
& 2 April 2018 & 13 \\
\hline
\end{tabular}




\begin{tabular}{lll}
\hline & Tanggal & SKOR \\
& 3 April 2018 & 93 \\
& 4 April 2018 & 77 \\
& 5 April 2018 & 73 \\
INTERVENSI & 10 April 2018 & 73 \\
& 12 April 2018 & 75 \\
& 16 April 2018 & 74 \\
& 18 April 2018 & 80 \\
\hline
\end{tabular}

Tabel 1 merupakan tabel pengukuran skor pemahaman matematis yang dilakukan selama sebelas hari. Pada kondisi baseline skor yang diperoleh siswa menunjukkan angka 13, 11, 10, 13. Pada sesi atau sesi pertama kondisi intervensi skor yang diperoleh siswa menunjukkan kenaikan yaitu 93, 77, 73, 73, 75, 74, 80. Seperti terdapat pada Gambar 1.

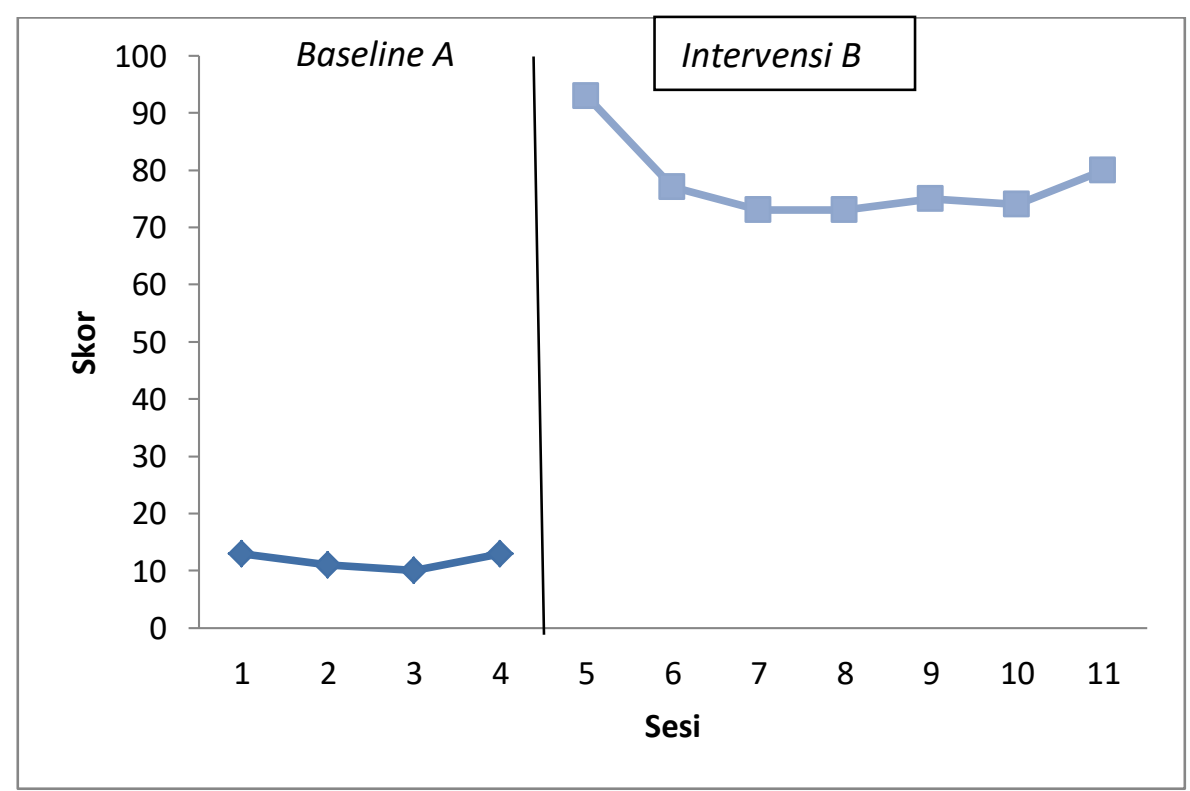

Gambar 1. Analisis visual baseline dan intervensi

\section{Analisis dalam Kondisi}

Analisis perubahan dalam kondisi adalah menganalisis perubahan data dalam satu kondisi, misalnya kondisi baseline atau kondisi intervensi, sedangkan komponen yang dianalisis meliputi komponen seperti tingkat stabilitas, kecenderungan arah, dan tingkat perubahan.

Komponen analisis dalam kondisi diatas jika dirangkum dapat dilihat pada Tabel 2. 
Tabel 2. Rangkuman Hasil Analisis Visual dalam Kondisi

\begin{tabular}{llcc}
\hline Kondisi & A1 & B2 \\
\hline 1. & Panjang Kondisi & 4 & 7 \\
\hline 2. & Estimasi Kecenderungan Arah & & \\
\hline 3. & Kecenderungan Stabilitas & Variabel (75\%) & Stabil $(85,71 \%)$ \\
\hline 4. & Kecenderungan Jejak & $=$ & $=$ \\
\cline { 2 - 2 } & 5. Level Stabilitas dan Rentang & Variabel & Stabil \\
\cline { 2 - 3 } \cline { 2 - 2 } & & $10,775-12,725$ & $70,905-84,855$ \\
\hline 6. & Level Perubahan & $\mathbf{1 3 - 1 3 = 0}$ & $\mathbf{9 3 - 8 0}=-\mathbf{1 3}$ \\
\hline
\end{tabular}

\section{Analisis Antar Kondisi}

Menganalisis antar kondisi, data yang stabil harus mendahului kondisi yang akan dianalisis, misalnya ketika data baseline bervariasi (tidak stabil), maka akan mengalami kesulitan untuk menginterpretasi pengaruh intervensi terhadap variabel terikat. Di samping aspek stabilitas, ada tidaknya pengaruh intervensi terhadap variabel terikat juga tergantung pada aspek perubahan level, dan besar kecilnya overlap yang terjadi antara dua kondisi yang sedang dianalisis.

Semakin kecil presentase overlap maka semakin baik pengaruh intervensi terhadap target behavior. Komponen antar kondisi diatas jika dirangkum dapat dilihat pada Tabel 3.

Tabel 3. Rangkuman hasil analisis visual antar kondisi

\begin{tabular}{llc}
\hline Perbandingan Kondisi & $\begin{array}{c}\boldsymbol{B}_{\mathbf{1}} / \boldsymbol{A}_{\mathbf{1}} \\
(2: 1)\end{array}$ \\
\hline 1. Jumlah variabel yang diubah & 1 \\
\hline 2. & Perubahan kecenderungan arah dan \\
& efeknya & $=$ \\
\hline 3. & Perubahan kecenderungan stabilitas & Variabel ke Stabil \\
\hline 4. & Perubahan level & $(\mathbf{1 3 - 9 3})=(-\mathbf{8 0})$ \\
\hline 5. & Presentase Overlap & $0 \%$ \\
\hline
\end{tabular}

\section{Pembahasan}

Dalam pelaksanaan penelitian, peneliti membimbing siswa dan melakukan pengamatan terhadap kerja siswa. Ruangan yang digunakan adalah ruang tamu di rumah siswa dan peneliti melakukan penelitian pada jam pulang sekolah. Penelitian ini dilakukan selama 11 hari pengamatan yang dilakukan pada dua kondisi yaitu empat hari pada kondisi baseline (A) sebelum diberikan intervensi, dan tujuh hari pada kondisi intervensi (B) setelah diberikan perlakuan. Pada analisis dalam kondisi, kondisi baseline (A) data yang diperoleh pada pengamatan pertama hingga pengamatan keempat yaitu 13,11, 10, 13 sehingga dari data yang diperoleh menunjukkan kecenderungan arah yang tetap. Pada kondisi intervensi (B) data yang diperoleh pada pengamatan pertama hingga pengamatan ketujuh yaitu 93, 77, 73, 73, 75, 74, 80 sehingga dari data yang diperoleh menunjukkan kecenderungan menurun. Pada analisis dalam kondisi, kondisi baseline kecenderungan stabilitas variabel atau tidak stabil dengan 
presentase $75 \%$, sedangkan kondisi intervensi kecenderungan stabilitas stabil dengan presentase $85,71 \%$. Sehingga, analisis antar kondisi menunjukkan presentase overlap 0\% dimana tidak terdapat data point pada kondisi intervensi yang berada pada rentang kondisi baseline.

Berdasarkan hasil wawancara, siswa penelitian menunjukkan adanya kesulitan belajar. Kesulitan belajar yang dialami siswa disebabkan ketidakpahaman siswa terhadap konsep matematika dan pemahaman matematis siswa terhadap operasi bilangan. Kesulitan belajar siswa tidak hanya disebabkan oleh ketidakpahaman siswa terhadap konsep dan pemahaman matematis tetapi juga disebabkan oleh pembelajaran yang dilakukan guru di dalam kelas yang membuat siswa menjadi tidak mengerti. Kesulitan yang dialami siswa, memungkinkan siswa melakukan kesalahan siswa melakukan kesalahan dalam menyelesaikan soal matematika pada setiap pokok bahasan dalam pembelajaran matematika (Untari, 2013; Kumalasari \& Sugiman, 2015). Kesulitan yang dialami siswa dalam belajar matematika dapat pula dimungkinkan karena siswa sulit dalam mempelajari materi matematika tertentu dan kesulitan yang dialami oleh siswa dapat dipengaruhi oleh berbagai aspek, seperti aspek kognitif dan aspek afektif (Aziz \& Sugiman, 2015). Sehingga, berdasarkan hasil penelitian sebelumnya bahwa kesulitan belajar dapat disebabkan oleh kesalahan dalam menyelesaikan soal matematika, aspek kognitif dan aspek afektif.

Penerapan pendekatan kontruktivisme yang telah dilaksanakan dalam penelitian ini adalah pembelajaran pada materi aturan sinus dan cosinus. Pada fase baseline, siswa mengerjakan lembar soal yang sudah disediakan untuk mengukur kemampuan awal siswa terhadap materi aturan sinus dan cosinus. pada fase ini siswa tidak dapat mengerjakan soal yang telah diberikan dikarenakan kurangnya pemahaman konsep matemtika pada materi aturan sinus dan cosinus, sehingga siswa hanya dapat menuliskan kembali yang diketahui dan ditanya pada soal., hal ini dapat dilihat pada Gambar 2.

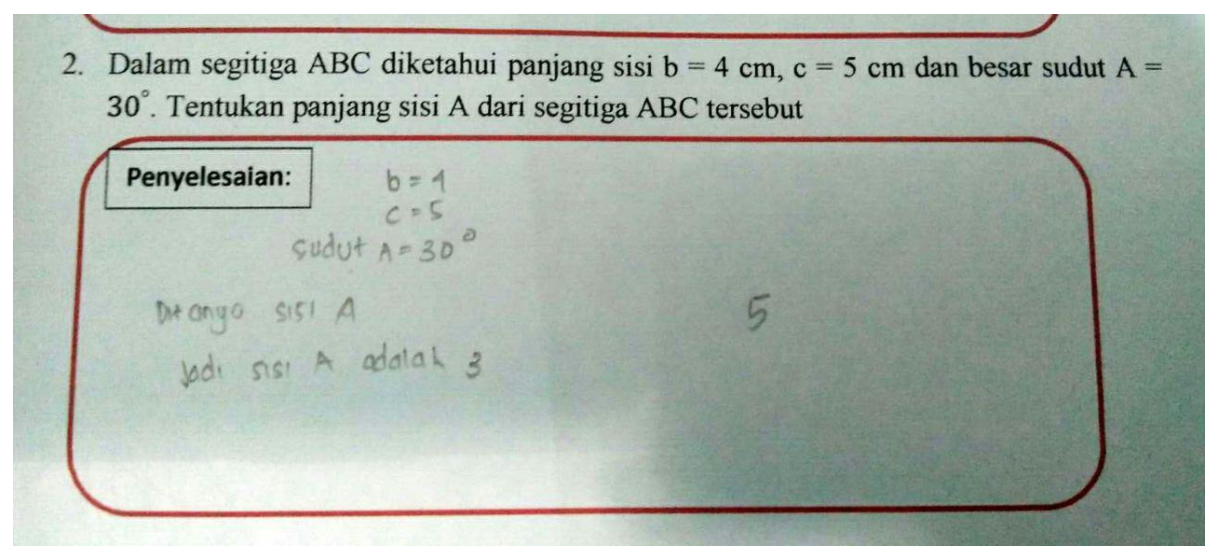

Gambar 2. Lembar Jawab Baseline

Kemudian pada fase intervensi ketiga siswa mengalami kesulitan dalam mengerjakan operasi bilangan yaitu ketika mengalikan suatu bilangan desimal dengan akar pecahan, dikarenakan rendahnya pemahaman matematis siswa, hal ini dapat dilihat pada Gambar 3. 
3. Diketahui segitiga $P Q R$, panjang sisi $Q R=7 \mathrm{~cm}, P R=9 \mathrm{~cm}$, dan besar sudut $P R Q=135$ Tentukan panjang sisi $\mathrm{PQ}$ !

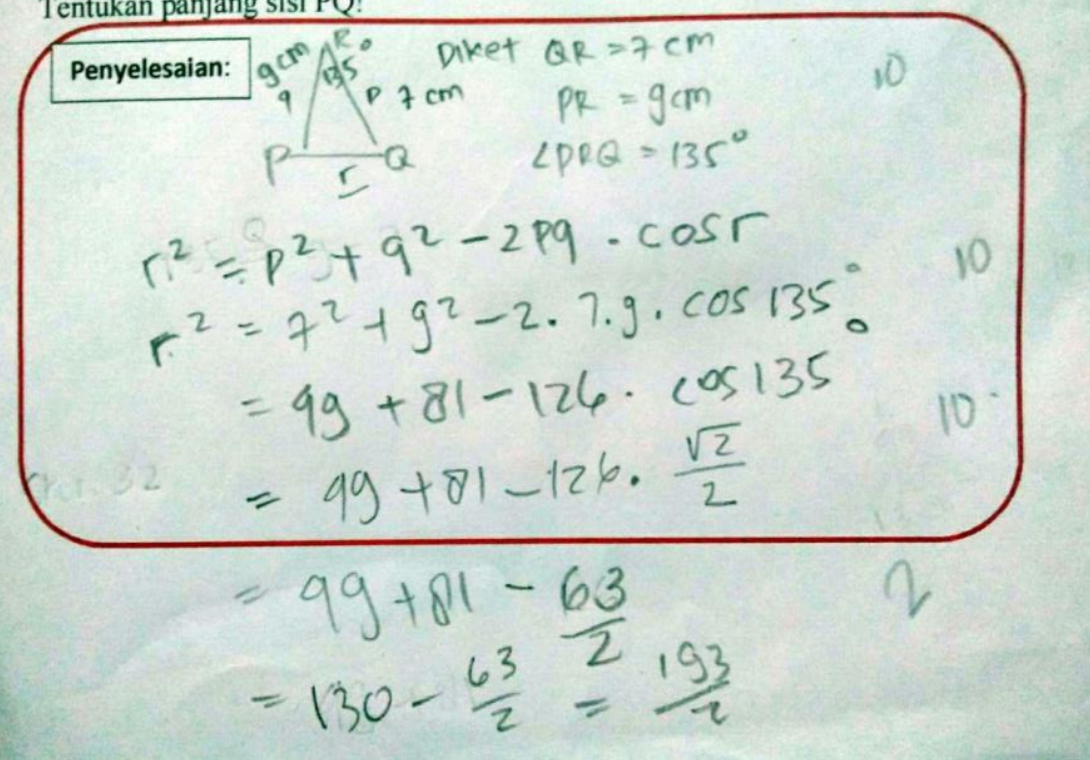

Gambar 3. Lembar Jawaban Siswa Intervensi 3

Kemudian pada fase intervensi selanjutnya, siswa diminta mengajukan pertanyaan tentang masalah yang dialami siswa dalam mengerjakan soal-soal sebelumnya, kemudian mendiskusikan masalah tersebut dengan peneliti. Kemudian, sebelumnya siswa diminta untuk mengingat dan meringkas kembali tentang materi yang telah didiskusikan sebelumnya dengan peneliti. Setelah masalah telah dimengerti siswa, siswa diminta untuk mengerjakan soal lagi untuk mengukur kemampuan siswa pada materi aturan sinus dan cosinus. pada sesi ini siswa sudah bisa mengerjakan soal aturan sinus dan cosinus, hal tersebut dapat di lihat pada Gambar 4.

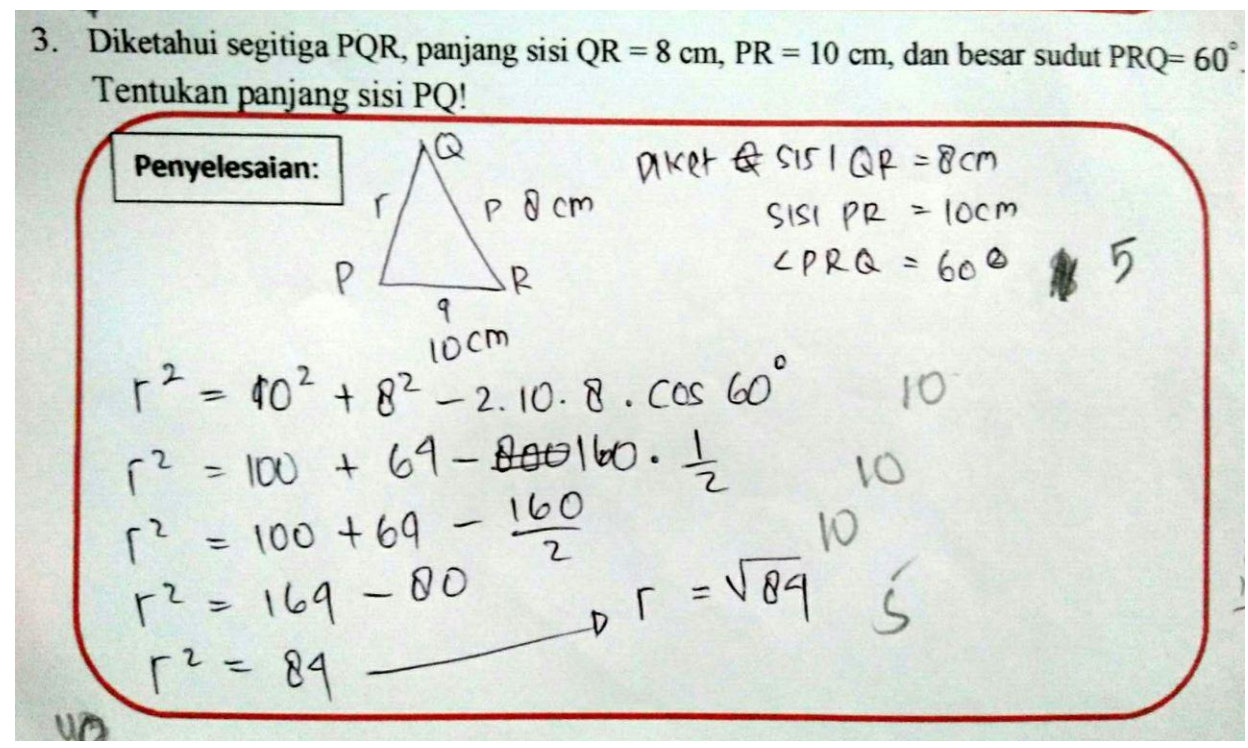

Gambar 4. Lembar Jawab Intervensi

Berdasarkan hasil penelitian, pendekatan kontruktivisme dapat meningkatkan pemahaman matematis siswa dalam operasi bilangan, dibuktikan dengan hasil wawancara yang tidak terdokumentasi terhadap guru matematika bahwa siswa yang menjadi siswa tunggal 
mengalami kemajuan dalam menyelesaikan masalah yang terkait dengan aturan sinus dan cosinus, sebelum mempelajari materi atuaran sinus dan cosinus guru tersebut membuat soal untuk dikerjakan, siswa merupakan salah satu yang dapat mengerjakan soal tersebut dengan cepat dan benar.

\section{KESIMPULAN}

Berdasarkan hasil dan pembahasan dapat diambil simpulan bahwa kurangnya pemahaman matematis siswa dan kesulitan yang dialami siswa dalam operasi bilangan disebabkan karena ketidakpahaman siswa terhadap konsep matematika dan pemahaman matematis siswa terhadap operasi bilangan. Kesulitan belajar siswa tidak hanya disebabkan oleh ketidakpahaman siswa terhadap konsep dan pemahaman matematis tetapi juga disebabkan oleh pembelajaran yang dilakukan guru di dalam kelas yang membuat siswa menjadi tidak mengerti. Oleh karena itu, pemahaman siswa pada kondisi baseline, dimana kondisi siswa sebelum diberikan perlakuan berada pada rata-rata skor 11,75 dengan skala 100. Perlakuan yang dilakukan berupan pendekatan kontruktivisme untuk meningkatkan pemahaman matematis siswa, sehingga setelah diberikan perlakuan, pemahaman matematis siswa meningkat, ditunjukkan dari rata-rata skor setelah diberikan perlakuan yaitu 77,88 dengan skala 100. Hal ini menunjukkan bahwa pendekatan kontruktivisme dapat meningkatkan pemahaman matematis siswa.

\section{DAFTAR PUSTAKA}

Alan, U. F., \& Afriansyah, E. A. (2017). Kemampuan Pemahaman Matematis Siswa Melalui Model Pembelajaran Auditory Intellectualy Repetition dan Problem Based Learning. Jurnal Pendidikan Matematika, 11(1), 67-78.

Arisandi, E. (2014). Meningkatkan Kemampuan Operasi Perkalian untuk Anak Diskalkulia Melalui Metode Garismatika. E-JUPEKhu, 3(3). 478-488.

Aristiani, N. (2013). Penggunaan Media Batang Napier dalam Meningkatkan Kemampuan Operasi Perkalian Bagi Anak Kesulitan Belajar Kelas 3 SD 11 Belakang Tangsi Padang. Jurnal Ilmiah Pendidikan Khusus, 1(1), 294-310.

Azis, A., \& Sugiman, S. (2015). Analisis kesulitan kognitif dan masalah afektif siswa SMA dalam belajar matematika menghadapi ujian nasional. Jurnal Riset Pendidikan Matematika, 2(2), 162-174.

Fauziah, K., Parta, I. N., \& Rahardjo, S. (2016). Pengembangan Lembar Kerja Siswa Materi Perkalian Matriks Bercirikan Penemuan Terbimbing untuk Siswa Smk Kelas X. Jurnal Pendidikan: Teori, Penelitian, dan Pengembangan, 1(9), 1721-1729.

Isnaeni, H. D. (2015). Penerapan Model Pembelajaran Kooperatif Tipe Team Accelerated Instruction (TAI) Untuk Meningkatkan Minat Dan Prestasi Belajar Siswa Kelas XII IPA 2 SMA Negeri 3 Bojonegoro Pada Pokok Bahasan Matrik Tahun Pelajaran 2012/2013. Jurnal Pendidikan Edutama, 2(2), 1-16.

Kesumawati, N. (2012). Meningkatkan Kemampuan Pemahaman Matematis Siswa SMP Melalui Pendekatan Pendidikan Matematika Realistik Indonesia (PMRI). Jurnal Pendidikan Matematika, 6(2), 30-44. 
Kumalasari, A., \& Sugiman, S. (2015). Analisis Kesulitan Belajar Mahasiswa Pada Mata Kuliah Kapita Selekta Matematika Sekolah Menengah. Jurnal Riset Pendidikan Matematika, 2(1), 16-27.

Ningsih, S. H., Budiyono, B., \& Riyadi, R. (2013). Eksperimentasi Model Pembelajaran Kooperatif Tipe Group Investigation (GI) Dan Think Pair Share (TPS) Pada Materi Trigonometri Ditinjau Dari Kecerdasan Logika Matematika Siswa Kelas X SMA di Kabupaten Sukoharjo. Jurnal Pembelajaran Matematika, 1(5), 479-489.

Niswarni, N. (2012). Peningkatan Hasil Belajar Program Linier Melalui Pendekatan Matematika Realistik Di Kelas X Jasa Boga 1 Sekolah Menengah Kejuruan Negeri 6 Palembang. Jurnal Pendidikan Matematika, 6(2), 19-29.

Noviandra, R., Sudaryati, S., \& Meiliasari. (2014). Mengembangkan Pemahaman Matematika Siswa Terhadap Materi Sistem Persamaan Linear Dua Variabel (SPLDV) Dengan Pendidikan Matematika Realistik Indonesia (PMRI) Di SMP Negeri 1 Tambun Selatan. Jurnal Matematika FMIPA UNJ, 13(1), 119-131.

Nurlita, M. (2015). Pengembangan Soal Terbuka (Open-Ended Problem) pada Mata Pelajaran Matematika SMP Kelas VIII. Jurnal pendidikan matematika. 10(1). 38-49.

Prahmana, R. C. I. (2010). Permainan “Tepuk Bergilir” yang Berorientasi Kontruktivisme dalam Pembelajaran Konsep KPK Siswa Kelas IV A Di SDN 21 Palembang. Jurnal Pendidikan Matematika, 4(2). 61-69.

Purnama, Afriansyah. (2016). Kemampuan Komunikasi Matematis Siswa Ditinjau Melalui Model Pembelajaran Kooperatif Tipe Complete Sentence dan Team Quis. Jurnal Pendidikan Matematika, 10(1), 26-42

Putri, J. D., Kriswandani, \& Wahyudi (2016). Analisis Kesalahan Menurut Newman dan Pemberian Scaffolding pada Materi Luas Segitiga dengan Aturan Sinus dan Cosinus Bagi Siswa XI MIA 1 SMA Kristen Satya Wacana Salatiga (Doctoral dissertation, Program Studi Pendidikan Matematika FKIP-UKSW).

Rahmawati. (2017). Desain Pembelajaran Penjumlahan Dan Pengurangan Pecahan Dengan Menggunakan Timbangan Siswa Kelas IV. Jurnal Pendidikan Matematika. 11(1). 57-68.

Ramellan, P., Musdi, E., \& Armiati. (2012). Kemampuan Komunikasi Matematis Dan Pembelajaran Interaktif. Jurnal Pendidikan Matematika, 1(1), 77-82.

Riyanto, B., \& Siroj, R. A. (2011). Meningkatkan Kemampuan Penalaran Dan Prestasi Matematika Dengan Pendekatan Konstruktivisme Pada Siswa Sekolah Menengah Atas. Jurnal Pendidikan Matematika, 5(1), 111-128.

Sari, W. M. (2013). Penggunaan Media Timbangan Bilangan untuk Meningkatkan Kemampuan Menjumlahkan Bagi Anak Tunagrahita Ringan. E-JUPEKhu, 2(1). 416-427.

Sunanto, J., Takeuchi, K., \& Nakata, H. (2005). Pengantar Penelitian Dengan Subjek Tunggal. Center for Research on International Cooperation in Education Development (CRICED) University of Tsukuba.

Syaban, M. (2009). Menumbuhkembangkan Daya Dan Disposisi Matematis Siswa Sekolah Menengah Atas Melalui Pembelajaran Investigasi. Jurnal Educationist, 3(2), 129136. 
298 Anggraeni, Prahmana, \& Ardhian, Perkembangan Siswa SMK Kelas X Pembelajaran ...

Ulfah, A. F., \& Prahmana, R. C. I. (2018). Single Subject Research: Implementasi Pembelajaran Berbasis Masalah terhadap Pemahaman Matematis Siswa. Jurnal Elemen, 4(1), 105-118.

Untari, E. (2013). Diagnosis Kesulitan Belajar Pokok Bahasan Pecahan Pada Siswa Kelas V Sekolah Dasar. Jurnal Ilmiah STKIP PGRI Ngawi, 13(01). 1-8. 